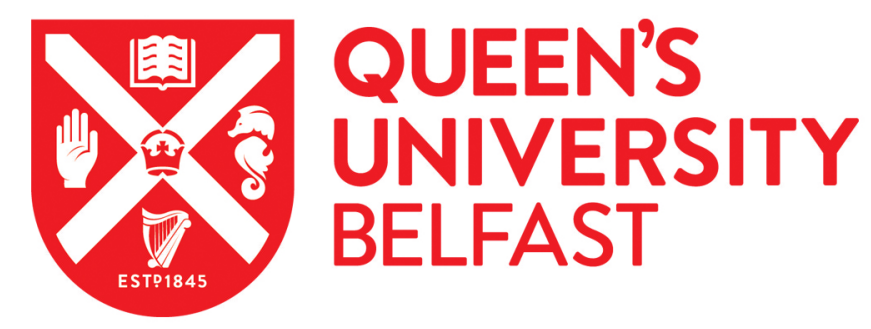

\title{
Influence of three arbuscular mycorrhizal fungi and phosphorus on growth and nutrient status of taro
}

Li, M., Liu, R. J., Christie, P., \& Li, X. L. (2005). Influence of three arbuscular mycorrhizal fungi and phosphorus on growth and nutrient status of taro. Communications in Soil Science and Plant Analysis, 36(17-18), 23832396. https://doi.org/10.1080/00103620500253134

Published in:

Communications in Soil Science and Plant Analysis

Queen's University Belfast - Research Portal:

Link to publication record in Queen's University Belfast Research Portal

\section{General rights}

Copyright for the publications made accessible via the Queen's University Belfast Research Portal is retained by the author(s) and / or other copyright owners and it is a condition of accessing these publications that users recognise and abide by the legal requirements associated with these rights.

Take down policy

The Research Portal is Queen's institutional repository that provides access to Queen's research output. Every effort has been made to ensure that content in the Research Portal does not infringe any person's rights, or applicable UK laws. If you discover content in the Research Portal that you believe breaches copyright or violates any law, please contact openaccess@qub.ac.uk. 


\title{
Influence of Three Arbuscular Mycorrhizal Fungi and Phosphorus on Growth and Nutrient Status of Taro
}

\author{
Min Li \\ Key Laboratory of Plant Nutrition, Ministry of Agriculture, \\ Key Laboratory of Plant-Soil Interactions, Ministry of Education, \\ and Department of Plant Nutrition, College of Agricultural Resources \\ and Environmental Sciences, China Agricultural University, Beijing, China \\ and Laiyang Agricultural College, Shandong, China

\section{Runjin Liu} \\ Laiyang Agricultural College, Shandong, China

\section{Peter Christie} \\ Key Laboratory of Plant Nutrition, Ministry of Agriculture, \\ Key Laboratory of Plant-Soil Interactions, Ministry of Education, \\ and Department of Plant Nutrition, College of Agricultural Resources \\ and Environmental Sciences, China Agricultural University, Beijing, China \\ and Agricultural and Environmental Science Department, \\ Queen's University, Belfast, United Kingdom

\section{Xiaolin Li} \\ Key Laboratory of Plant Nutrition, Ministry of Agriculture, \\ Key Laboratory of Plant-Soil Interactions, Ministry of Education, \\ and Department of Plant Nutrition, College of Agricultural Resources \\ and Environmental Sciences, China Agricultural University, Beijing, China
}

\footnotetext{
Abstract: Glasshouse and field experiments were conducted with micropropagated (tissue culture) taro plants and germinated corms to determine the arbuscular mycorrhizal dependency of taro. The micropropagated plants (cultivar Laiyu 3) were

Received 8 October 2004, Accepted 11 June 2005

Address correspondence to Xiaolin Li, Department of Plant Nutrition, College of Resources and Environment, P.R. China Agricultural University, Beijing 100094, China. Fax: +8610 62731016; E-mail: lixl@cau.edu.cn
} 
transplanted in plastic pots (3-L) containing a mixture of vermiculite:perlite:peat:sand (2:1:1:1) with 0 or 8000 units of inoculum potential (UIP) of Glomus mosseae (Nicol \& Gerd) Gerdemann and Trappe, Glomus versiforme (Karsten) Berch or Gigaspora rosea Nicolson \& Schenck. Budded corms were planted in clay pots (8.5-L) containing sterilized sandy loam mixed with 0 or 12,000 UIP of G. mosseae or G. versiforme, and 0 or $5 \mathrm{~g} \mathrm{Ca}_{3}\left(\mathrm{PO}_{4}\right)_{2}$ were added. In a field experiment, budded corms were placed in paper pots $(0.5-\mathrm{L})$ with sterilized sandy loam mixed with 0 or 4000 UIP of G. mosseae or G. versiforme and then planted directly in the field. Inoculation with AM fungi significantly increased survival rate and growth of tissue culture taro plants, and the contents of nitrogen $(\mathrm{N})$, phosphorus $(\mathrm{P})$, potassium $(\mathrm{K})$, calcium (Ca), copper $(\mathrm{Cu})$, and zinc $(\mathrm{Zn})$, enhanced the formation of corms, numbers of second and third branch corms and corm yield, and enhanced the contents of crude protein, starch, and amino acids in the corms. Phosphorus fertilizer slightly increased plant yield but reduced plant absorption of $\mathrm{Cu}$ and $\mathrm{Zn}$ and root colonization by the AM fungi. Relative mycorrhizal dependence (RMD) of micropropagated plants was greater than that of corms.

Keywords: AM fungi, taro, phosphorus, mycorrhizal dependency, corms, micropropated plants

\section{INTRODUCTION}

Taro [Colocasia esculenta (L.) Schott] is an important root and food crop in the south Pacific, the Caribbean basin, Africa and south Asia (Goenaga et al. 1991). It has been grown from ancient times in China and was defined as a special product in 1913 at the First Vegetable Product Fair in Shandong Province, northeast China. High-quality tubers of taro, especially those produced in Laiyang City, Shandong Province, are now a major export vegetable. Taro is characterized by a long growing period and high fertilizer requirement, especially nitrogen $(\mathrm{N})$, phosphorus $(\mathrm{P})$, potassium $(\mathrm{K})$, and calcium $(\mathrm{Ca})$. Its mineral nutrient uptake and mineral use efficiency have been studied in recent years (Kabeerathumma et al. 1985; Jacobs and Clarke 1993; Kubuabola et al. 2000) together with rapid vegetative multiplication techniques (Chand et al. 1999). In addition, differences between cultivars in nutrient absorption (Goenaga and Chardon 1995) and the influence of planting season on accumulation of dry matter and $\mathrm{N}$ have been investigated (Chan et al. 1999). However, current yield levels in taro production are relatively low both in unit area and total yield (FAO 1999). Unfortunately, few data are available on response of taro to AM fungi, despite the possibility that the crop may be dependent on AM fungi due to the morphology of the root system, typically with coarse roots and relatively few roots per plant. In the present study, pot and field experiments were conducted with budded corms and micropropagated taro plants from tissue culture to investigate the impact of AM fungal colonization on taro growth and nutrient status. 


\section{MATERIALS AND METHODS}

\section{Experimental Designs}

Three experiments were conducted. Experiment 1 was conducted with budded corms grown in pots to determine the effects of AM fungal inoculation and added $\mathrm{P}$ on taro under controlled conditions. Sandy loam soil of $\mathrm{pH} 7.5$ (in water), containing $0.97 \%$ organic matter, $0.06 \%$ total $\mathrm{N}, 0.07 \%$ total $\mathrm{P}$, $12.5 \mathrm{mg} \mathrm{kg}^{-1}$ available $\mathrm{P}$ (Olsen P extracted with $\mathrm{NaHCO}_{3}$ ), and $70 \mathrm{mg}$ $\mathrm{kg}^{-1}$ exchangeable $\mathrm{K}$ was sieved and sterilized $\left(121^{\circ} \mathrm{C}, 2 \mathrm{~h}\right)$. Soil (8.5-L) was placed in pots. There were uninoculated control pots and pots inoculated with Glomus mosseae (Nicol \& Gerd) Gerdemann and Trappe or Glomus versiforme (Karsten) Berch with or without $5 \mathrm{~g}$ of $\mathrm{Ca}_{3}\left(\mathrm{PO}_{4}\right)_{2}$ added to the soil. Thus, there were 6 treatments and 15 replicates, giving a total of 90 pots in a fully randomized design. Budded "Laiyang Guyu" corms were planted in the pots containing sterilized loam mixed with $30 \mathrm{~mL}$ (per pot) of inoculum (about 12,000 units of inoculum potential (UIP) of the AM fungi (Liu and Luo 1994). Control pots received the same amount of sterilized $\left(121^{\circ} \mathrm{C}, 2 \mathrm{~h}\right)$ inoculum. The experiment was conducted in a glasshouse with a day/night temperature regimen of $25-30^{\circ} \mathrm{C} / 15-20^{\circ} \mathrm{C}$. One seedling was grown in each pot, and soil moisture was maintained at about $80 \%$ of water-holding capacity (WHC). Hoagland nutrient solution (30\% strength) without $\mathrm{P}$ was given every 2 weeks.

Experiment 2 was a field experiment conducted at Zhao Wang Zhuang $\left(37^{\circ} 57^{\prime} \mathrm{N}, 120^{\circ} 49^{\prime} \mathrm{E}\right)$, in Laiyang City, Shandong Province, northeast China, to evaluate the effects of AM fungi on taro growth under field conditions. The field area was $840 \mathrm{~m}^{2}(40 \mathrm{~m} \times 21 \mathrm{~m})$. The sandy loam soil contained $0.76 \%$ organic matter, $0.05 \%$ total $\mathrm{N}, 0.08 \%$ total $\mathrm{P}, 10.3 \mathrm{mg}$ $\mathrm{kg}^{-1}$ Olsen $\mathrm{P}$, and $65.5 \mathrm{mg} \mathrm{kg}^{-1}$ exchangeable $\mathrm{K}$ and had a $\mathrm{pH}$ of 6.7 . Laiyang Guyu corms were planted in paper pots $(0.5-\mathrm{L})$ containing sterilized sandy loam with one of three treatments: 1) control with sterilized inoculum mixed with the soil, 2) 4000 UIP of G. mosseae (Nicol \& Gerd) Gerdemann, and 3) Trappe inoculum and G. versiforme (Karsten) Berch inoculum. The paper pots were immediately planted in a field, with a row spacing of $0.80 \mathrm{~m}$ and pot spacing of $0.42 \mathrm{~m}$ (planting density three pots $\mathrm{m}^{-2}$ ). All treatments were arranged at random, and each contained three plots, and each plot contained six rows. Protective buffer rows were set up along both sides. Weeds were controlled by hand on five occasions and no herbicides were applied. At the early stages of corm development, a single application of a complex NPK fertilizer (21:8:11; produced by BASF in Germany) was made to each plot at a rate of $90 \mathrm{~g} \mathrm{~m}^{-2}$. The field was irrigated to about $80 \%$ of field capacity when the plants started to show signs of drought.

Experiment 3 was conducted from May to September 2000 using micropropagated (tissue culture) taro (cultivar "Laiyu 3") to investigate the 
mycorrhizal dependency of plants produced by using tissue culture. Tissue culture was carried out in Erlenmeyer flasks $(100-\mathrm{mL})$ from 10 February to 30 April 2000. A taro bud tip $0.5 \mathrm{~mm}$ in length with about one or two leaf primordia was used to induce budding on Murashige and Skoog (MS) medium (Murashige and Skoog 1962) containing $0.2 \mathrm{mg} \mathrm{L}^{-1} 1$-naphthalacetic acid (NAA) and $2.0 \mathrm{mg} \mathrm{L}^{-1}$ 6-benzyladenine (6-BA) and then transferred to MS medium until plants with a few roots and two or three leaves were produced. The roots were gently washed to remove any agar medium and transplanted into plastic pots (3-L) containing a sterilized mixture of vermiculite:perlite:peat:sand (2:1:1:1 w/w) and mixed with $20 \mathrm{~mL}$ (8000 UIP) of Glomus mosseae (Nicol \& Gerd) Gerdemann and Trappe, Glomus versiforme (Karsten) Berch or Gigaspora rosea Nicolson \& Schenck inoculum. Control pots received the same amount of sterilized inoculum. The rooting mixture contained $0.70 \%$ organic matter, $0.05 \%$ total $\mathrm{N}, 0.075 \%$ total $\mathrm{P}, 18.0 \mathrm{mg} \mathrm{kg}^{-1}$ Olsen $\mathrm{P}$, and $49.5 \mathrm{mg} \mathrm{kg}^{-1}$ available $\mathrm{K}$, with a $\mathrm{pH}$ of 6.5 . There were 4 treatments with 15 replicate pots arranged in 3 randomized blocks. The experiment was conducted in a glasshouse with $25-30^{\circ} \mathrm{C} / 15-20^{\circ} \mathrm{C}$ day/night temperature regimen. Pots were watered every 3 days and adjusted to about $80 \%$ WHC, and 30\% Hoagland nutrient solution without P was added every two weeks.

\section{Assessment of Variables}

Height, dry weight, leaf numbers, and leaf surface area per plant, and relative mycorrhizal dependence (RMD) were determined (Plenchette et al. 1983) in Experiment 160 days after inoculation. Plant survival rate, numbers of corms, second and third branch corms, corm yield, RMD, and economic coefficient $[\mathrm{EC}=$ Dry weight of economic organ/total dry weight (biomass) per plant (i.e., dry weight of corms/total dry weight per plant, calculated in this article)] were determined in Experiment 3 at harvest. Mycorrhizal colonization of the roots (Biermann and Linderman 1981) of plants grown in clay pots in the field experiment was determined 60 days after inoculation. The harvested corms were used to determine the following quality parameters. After hydrolysis with $\mathrm{HCl}$, the content of amino acids in corms was determined with a Hitachi 835-50 Automatic Amino-Acid Analyzer (Li et al. 1997). Soluble sugar and starch were measured by using the anthrone colorimetric method. The P concentration in plant tissue was determined with an Inductively Coupled Plasma spectrometer (Perkin Elmer Optima 3300DV). Other mineral elements were determined with a Hitachi Z-8000 Atomic Absorption Spectrophotometer (Li et al. 1997). Crude protein was analyzed by the Kjeldahl nitrogen method. The data obtained were analyzed statistically by using the SAS software package (Hatcher and Stepanski 1994). 


\section{RESULTS}

\section{Colonization of Taro Roots by AM Fungi}

Table 1 shows the mycorrhizal colonization status on taro roots in the three experiments. In Experiment 1, 60 days after inoculation, the proportion of root length colonized was 42.3-65.5\%, occurrence of arbuscules was $30.1-49.6 \%$, and P fertilizer significantly reduced mycorrhizal colonization, occurrence of arbuscules and the numbers of entry points under pot conditions. In Experiment 2 under field conditions, mycorrhizal colonization reached the level in the pot experiment, and there was negligible colonization (2.8\%) attributable to indigenous AM fungi on the control plants. In Experiment 3, the total proportion of root length colonized by all three AM fungi tested was greater than $90 \% 60$ days after inoculation (Table 1).

\section{Effects of AM Fungi on Mineral Elements in Taro Plants}

Concentrations of $\mathrm{N}, \mathrm{P}, \mathrm{K}, \mathrm{Cu}$, and $\mathrm{Zn}$ in roots and leaves of taro plants were significantly increased by inoculation with $G$. mosseae and G. versiforme, and the effect was usually more pronounced with colonization by G. versiforme. Phosphorus fertilizer enhanced plant $\mathrm{P}$ concentrations, decreased $\mathrm{Zn}$ and $\mathrm{Cu}$

Table 1. Mean colonization status of arbuscular mycorrhizal fungi on roots of taro plants 60 days after inoculation with arbuscular mycorrhizal fungal inoculum

\begin{tabular}{|c|c|c|c|c|}
\hline $\begin{array}{l}\text { Experiment and } \\
\text { treatment }\end{array}$ & $\begin{array}{l}\text { Colonization } \\
\text { (\% of root } \\
\text { length) }\end{array}$ & $\begin{array}{c}\text { Arbuscules } \\
(\%)\end{array}$ & $\begin{array}{l}\text { Entry points } \\
\text { (no. } \mathrm{mm}^{-1} \\
\text { root length) }\end{array}$ & $\begin{array}{c}\text { Vesicles } \\
\text { (no. } \mathrm{mm}^{-1} \\
\text { root length) }\end{array}$ \\
\hline \multicolumn{5}{|l|}{ Experiment 1} \\
\hline G. mosseae & $57.6 \mathrm{a}^{a}$ & $42.5 \mathrm{a}$ & $4.6 \mathrm{a}$ & $1.4 \mathrm{a}$ \\
\hline G. versiforme & $65.5 \mathrm{a}$ & $49.6 \mathrm{a}$ & $4.1 \mathrm{a}$ & $1.9 \mathrm{a}$ \\
\hline G. mosseae $+\mathrm{P}$ & $42.3 \mathrm{~b}$ & $30.1 \mathrm{~b}$ & $2.3 \mathrm{~b}$ & $0.9 \mathrm{a}$ \\
\hline G. versiforme $+\mathrm{P}$ & $45.2 \mathrm{~b}$ & $32.4 \mathrm{~b}$ & $2.8 \mathrm{~b}$ & $1.1 \mathrm{a}$ \\
\hline \multicolumn{5}{|l|}{ Experiment 2} \\
\hline G. mosseae & $55.3 \mathrm{a}$ & $38.4 \mathrm{a}$ & $3.2 \mathrm{a}$ & $1.0 \mathrm{a}$ \\
\hline G. versiforme & $59.4 \mathrm{a}$ & $42.3 \mathrm{a}$ & $3.6 \mathrm{a}$ & $1.2 \mathrm{a}$ \\
\hline Uninoculated & $2.8 \mathrm{~b}$ & 00.0 & $0.1 \mathrm{~b}$ & $0.0 \mathrm{~b}$ \\
\hline \multicolumn{5}{|l|}{ Experiment 3} \\
\hline Gi. rosea & $91.0 \mathrm{a}$ & $53.7 \mathrm{~b}$ & $6.9 \mathrm{~b}$ & 0.0 \\
\hline G. mosseae & $91.5 \mathrm{a}$ & $57.1 \mathrm{ab}$ & $7.2 \mathrm{ab}$ & $6.2 \mathrm{a}$ \\
\hline G. versiforme & $95.2 \mathrm{a}$ & $63.2 \mathrm{a}$ & $8.8 \mathrm{a}$ & $7.1 \mathrm{a}$ \\
\hline
\end{tabular}

${ }^{a}$ Within each parameter in each experiment, means followed by the same letter are not significantly different by least significant difference at the $5 \%$ level. 
concentrations, and led to interactions among $\mathrm{P}, \mathrm{Zn}$, and $\mathrm{Cu}$ concentrations (Table 2).

\section{Effects of AM Fungi on Growth, Yield, Quality, and Mycorrhizal Dependence of Taro}

Treatment with $G$. mosseae and $G$. versiforme significantly enhanced growth and development of taro plants. Plant height, leaf area, and leaf and root dry weights were greater than that of controls. The most striking results were obtained with $G$. versiforme. Plant growth was enhanced by $\mathrm{P}$ fertilizer, but there were no significant differences between AM fungi treatments (Table 3).

Table 4 shows that the AM fungi tested significantly increased the survival rate of the micropropagated transplanted plants, and the dry weight and economic coefficient of corms. Control plants did not form second corms. It has been suggested that AM fungi may promote the formation of plant organs of economic importance. Under field conditions, the yield in treatments with $G$. mosseae and $G$. versiforme increased by $56.8 \%$ and $60.9 \%$, respectively, compared with the control. Water content was reduced, whereas crude protein, amino acids, and starch contents were significantly enhanced (Table 5).

The RMD of micropropagated taro plants was from 66.9 to $71.6 \%$ greater than that of taro corm plants, which ranged from 36.9 to $49.5 \%$ (Tables 3 and 4). The results indicate that taro had a strong dependence on the mycorrhizal fungi.

\section{DISCUSSION}

Miyasaka and Habte (2001) studied the P uptake efficiency of a number of arbuscular mycorrhizal trees and food crops and used their results to allocate the plant species tested into one of three categories of mycorrhizal dependency: moderately, highly, and very highly dependent. They found taro to be moderately dependent under their experimental conditions. In contrast to Potty (1978), this study found that taro plant roots, especially those derived from tissue culture, formed typical arbuscular mycorrhizal structures. The present experiments indicate that the formation of mycorrhiza enhanced plant $\mathrm{N}, \mathrm{P}, \mathrm{K}$, and Ca uptake and use, increased the growth of roots and shoots, and increased yield and quality. These data indicate that the taro plants had a strong mycorrhizal dependence. Although P application also had some positive effects on taro, $\mathrm{P}$ fertilizer led to $\mathrm{P}-\mathrm{Zn}-\mathrm{Cu}$ interactions, and the AM fungi tended to reduce this interaction, and this is in agreement with the earlier work by Liu (1989). However, different AM fungi had different efficiencies, with Glomus versiforme being the most effective symbiont on taro. On the other hand, because of differences in nutrient use efficiency between 
Table 2. Effects of arbuscular mycorrhizal fungi on mineral element composition of taro plants ${ }^{a}$

\begin{tabular}{|c|c|c|c|c|c|c|c|c|}
\hline \multirow{2}{*}{$\begin{array}{l}\text { Experiment and } \\
\text { treatment }\end{array}$} & \multicolumn{5}{|c|}{ DM\% } & \multicolumn{3}{|c|}{$\mathrm{DM}(\mathrm{mg} / \mathrm{kg})$} \\
\hline & $\mathrm{N}$ & $P$ & $\mathrm{~K}$ & $\mathrm{Ca}$ & $\mathrm{Mg}$ & $\mathrm{Zn}$ & $\mathrm{Cu}$ & $\mathrm{Mn}$ \\
\hline \multicolumn{9}{|l|}{ Experiment 1} \\
\hline \multicolumn{9}{|l|}{ Leaves } \\
\hline G. mosseae & $2.20 \mathrm{a}^{b}$ & $0.33 \mathrm{~b}$ & $4.00 \mathrm{a}$ & $1.60 \mathrm{a}$ & $0.21 \mathrm{a}$ & $29.7 \mathrm{a}$ & $10.0 \mathrm{a}$ & $21.1 \mathrm{a}$ \\
\hline G. versiforme & $2.24 \mathrm{a}$ & $0.36 \mathrm{~b}$ & $4.05 \mathrm{a}$ & $1.64 \mathrm{a}$ & $0.20 \mathrm{a}$ & $30.7 \mathrm{a}$ & $10.6 \mathrm{a}$ & $21.5 \mathrm{a}$ \\
\hline G. mosseae $+\mathrm{P}$ & $2.28 \mathrm{a}$ & $0.43 \mathrm{a}$ & $4.07 \mathrm{a}$ & $1.63 \mathrm{a}$ & $0.22 \mathrm{a}$ & $14.8 \mathrm{c}$ & $7.7 \mathrm{~b}$ & $22.3 \mathrm{a}$ \\
\hline G. versiforme $+\mathrm{P}$ & $2.33 \mathrm{a}$ & $0.47 \mathrm{a}$ & $4.16 \mathrm{a}$ & $1.68 \mathrm{a}$ & $0.23 \mathrm{a}$ & $16.5 \mathrm{c}$ & $7.9 \mathrm{~b}$ & $23.1 \mathrm{a}$ \\
\hline Control & $1.89 \mathrm{~b}$ & $0.29 \mathrm{c}$ & $3.58 \mathrm{~b}$ & $1.43 \mathrm{~b}$ & $0.19 \mathrm{a}$ & $26.3 \mathrm{~b}$ & $8.8 \mathrm{~b}$ & $20.4 \mathrm{a}$ \\
\hline Control $+\mathrm{P}$ & $1.97 \mathrm{~b}$ & $0.35 \mathrm{~b}$ & $3.61 \mathrm{~b}$ & $1.47 \mathrm{~b}$ & $0.20 \mathrm{a}$ & $10.4 \mathrm{~d}$ & $5.7 \mathrm{c}$ & $21.9 \mathrm{a}$ \\
\hline \multicolumn{9}{|l|}{ Roots } \\
\hline G. mosseae & $1.80 \mathrm{a}$ & $0.30 \mathrm{~b}$ & $2.01 \mathrm{a}$ & $1.92 \mathrm{~b}$ & $0.16 \mathrm{a}$ & $27.6 \mathrm{a}$ & $11.1 \mathrm{a}$ & $28.8 \mathrm{a}$ \\
\hline G. versiforme & $1.84 \mathrm{a}$ & $0.32 \mathrm{~b}$ & $2.37 \mathrm{a}$ & $2.09 \mathrm{~b}$ & $0.15 \mathrm{a}$ & $28.9 \mathrm{a}$ & $11.3 \mathrm{a}$ & $28.6 \mathrm{a}$ \\
\hline G. mosseae $+\mathrm{P}$ & $1.87 \mathrm{a}$ & $0.41 \mathrm{a}$ & $2.28 \mathrm{a}$ & $2.47 \mathrm{a}$ & $0.17 \mathrm{a}$ & $24.0 \mathrm{~b}$ & $10.0 \mathrm{a}$ & $29.4 \mathrm{a}$ \\
\hline G. versiforme $+\mathrm{P}$ & $1.91 \mathrm{a}$ & $0.45 \mathrm{a}$ & $2.39 \mathrm{a}$ & $2.53 \mathrm{a}$ & $0.16 \mathrm{a}$ & $24.6 \mathrm{~b}$ & $10.3 \mathrm{a}$ & $29.6 \mathrm{a}$ \\
\hline Control & $1.16 \mathrm{~b}$ & $0.20 \mathrm{c}$ & $1.40 \mathrm{~b}$ & $1.68 \mathrm{c}$ & $0.15 \mathrm{a}$ & $24.3 \mathrm{~b}$ & $10.9 \mathrm{a}$ & $27.6 \mathrm{a}$ \\
\hline Control $+\mathrm{P}$ & $1.64 \mathrm{~b}$ & $0.33 \mathrm{~b}$ & $1.51 \mathrm{~b}$ & $1.74 \mathrm{c}$ & $0.15 \mathrm{a}$ & $21.6 \mathrm{c}$ & $9.8 \mathrm{a}$ & $28.6 \mathrm{a}$ \\
\hline \multicolumn{9}{|l|}{ Experiment 2} \\
\hline \multicolumn{9}{|l|}{ Roots } \\
\hline G. mosseae & $1.82 \mathrm{a}$ & $0.33 \mathrm{a}$ & $2.21 \mathrm{a}$ & $1.97 \mathrm{a}$ & $0.16 \mathrm{a}$ & $28.2 \mathrm{a}$ & 11.3 & $27.1 \mathrm{a}$ \\
\hline G. versiforme & $1.88 \mathrm{a}$ & $0.35 \mathrm{a}$ & $2.43 \mathrm{a}$ & $2.14 \mathrm{a}$ & $0.17 \mathrm{a}$ & $29.1 \mathrm{a}$ & 11.8 & $27.4 \mathrm{a}$ \\
\hline
\end{tabular}


Table 2. Continued

\begin{tabular}{|c|c|c|c|c|c|c|c|c|}
\hline \multirow{2}{*}{$\begin{array}{l}\text { Experiment and } \\
\text { treatment }\end{array}$} & \multicolumn{5}{|c|}{ DM\% } & \multicolumn{3}{|c|}{$\mathrm{DM}(\mathrm{mg} / \mathrm{kg})$} \\
\hline & $\mathrm{N}$ & $\mathrm{P}$ & $\mathrm{K}$ & $\mathrm{Ca}$ & $\mathrm{Mg}$ & $\mathrm{Zn}$ & $\mathrm{Cu}$ & $\mathrm{Mn}$ \\
\hline $\begin{array}{c}\text { Control } \\
\text { Experiment } 3\end{array}$ & $1.19 \mathrm{~b}$ & $0.22 \mathrm{~b}$ & $1.45 \mathrm{~b}$ & $1.73 \mathrm{~b}$ & $0.16 \mathrm{a}$ & $25.6 \mathrm{~b}$ & 11.0 & $25.4 \mathrm{a}$ \\
\hline \multicolumn{9}{|l|}{$\begin{array}{l}\text { Experiment } 3 \\
\text { Roots }\end{array}$} \\
\hline Gi. rosea & $1.68 \mathrm{a}$ & $0.29 \mathrm{a}$ & $2.10 \mathrm{a}$ & $2.05 \mathrm{a}$ & $0.16 \mathrm{a}$ & $26.0 \mathrm{a}$ & 9.9 & $26.7 \mathrm{a}$ \\
\hline G. mosseae & $1.70 \mathrm{a}$ & $0.31 \mathrm{a}$ & $2.14 \mathrm{a}$ & $1.98 \mathrm{a}$ & $0.17 \mathrm{a}$ & $27.0 \mathrm{a}$ & 11.0 & $27.1 \mathrm{a}$ \\
\hline G. versiforme & $1.76 \mathrm{a}$ & $0.33 \mathrm{a}$ & $2.21 \mathrm{a}$ & $2.07 \mathrm{a}$ & $0.16 \mathrm{a}$ & $27.4 \mathrm{a}$ & 10.0 & $27.0 \mathrm{a}$ \\
\hline Control & $1.04 \mathrm{~b}$ & $0.20 \mathrm{~b}$ & $1.49 \mathrm{~b}$ & $1.75 \mathrm{~b}$ & $0.15 \mathrm{a}$ & $23.7 \mathrm{~b}$ & 10.0 & $26.4 \mathrm{a}$ \\
\hline
\end{tabular}

${ }^{a}$ Data were determined at the final harvest.

${ }^{b}$ Within each column in each experiment, means followed by the same letter are not significantly different by least significant difference at the $5 \%$ level. 
Table 3. Effects of arbuscular mycorrhizal fungi and $\mathrm{P}$ on growth and development of taro grown in pots $\left(\right.$ Experiment 1) ${ }^{a}$

\begin{tabular}{lccccccc}
\hline Treatment & $\begin{array}{c}\text { Number of } \\
\text { roots }\end{array}$ & $\begin{array}{c}\text { Plant height } \\
(\mathrm{cm})\end{array}$ & $\begin{array}{c}\text { Number of } \\
\text { leaves }\end{array}$ & $\begin{array}{c}\text { Leaf dry } \\
\text { weight }(\mathrm{g})\end{array}$ & $\begin{array}{c}\text { Root dry } \\
\text { weight }(\mathrm{g})\end{array}$ & $\begin{array}{c}\text { RMD } \\
(\%)\end{array}$ & $\begin{array}{c}\text { Leaf area } \\
\left(\mathrm{cm}^{2}\right)\end{array}$ \\
\hline G. mosseae & $44 \mathrm{a}^{b}$ & $48 \mathrm{a}$ & 5 & $12.45 \mathrm{~b}$ & $3.24 \mathrm{~b}$ & 45.1 & $394 \mathrm{~b}$ \\
G. versiforme & $47 \mathrm{a}$ & $48 \mathrm{a}$ & 5 & $13.08 \mathrm{ab}$ & $3.69 \mathrm{ab}$ & 49.5 & $463 \mathrm{a}$ \\
G. mosseae $+\mathrm{P}$ & $43 \mathrm{a}$ & $45 \mathrm{a}$ & 5 & $12.84 \mathrm{~b}$ & $3.27 \mathrm{~b}$ & 36.9 & $446 \mathrm{ab}$ \\
G. versiforme $+\mathrm{P}$ & $51 \mathrm{a}$ & $52 \mathrm{a}$ & 5 & $15.57 \mathrm{a}$ & $3.15 \mathrm{a}$ & 48.7 & $481 \mathrm{a}$ \\
Control & $28 \mathrm{~b}$ & $25 \mathrm{~b}$ & 4 & $6.72 \mathrm{c}$ & $1.71 \mathrm{c}$ & - & $286 \mathrm{c}$ \\
Control $+\mathrm{P}$ & $32 \mathrm{~b}$ & $33 \mathrm{~b}$ & 5 & $7.71 \mathrm{c}$ & $2.52 \mathrm{c}$ & - & $291 \mathrm{c}$ \\
\hline
\end{tabular}

${ }^{a}$ Plant height, leaf numbers, and leaf root dry weights were measured 60 days after inoculation. RMD, relative mycorrhizal dependence.

${ }^{b}$ Within each column, means followed by the same letter are not significantly different by LSD at the $5 \%$ level. 
Table 4. Effects of arbuscular mycorrhizal fungi on survival rates, growth and mycorrhizal dependence of micropropagated taro plants (Experiment 3) ${ }^{a}$

\begin{tabular}{|c|c|c|c|c|c|c|}
\hline Treatment & $\begin{array}{c}\text { Survival rate } \\
(\%)\end{array}$ & $\begin{array}{l}\text { Dry weight of leaves } \\
\quad\left(\mathrm{g} \text { plant }^{-1}\right)\end{array}$ & $\begin{array}{l}\text { Dry weight of roots } \\
\quad(\mathrm{g} \text { plant } \\
-1)\end{array}$ & $\begin{array}{l}\text { Dry weight of corms } \\
\left.\text { (g plant }^{-1}\right)\end{array}$ & $\begin{array}{l}\text { Economic } \\
\text { coefficient }\end{array}$ & $\begin{array}{l}\mathrm{RMD} \\
(\%)\end{array}$ \\
\hline Gi. rosea & $97 a b^{b}$ & $3.20 \mathrm{a}$ & $0.79 \mathrm{a}$ & $2.42 \mathrm{a}$ & $0.376 \mathrm{a}$ & 66.9 \\
\hline G. mosseae & $100 \mathrm{a}$ & $3.22 \mathrm{a}$ & $0.83 \mathrm{a}$ & $2.53 \mathrm{a}$ & $0.383 \mathrm{a}$ & 67.7 \\
\hline G. versiforme & $100 \mathrm{a}$ & $3.66 \mathrm{a}$ & $1.01 \mathrm{a}$ & $2.95 \mathrm{a}$ & $0.692 \mathrm{a}$ & 71.6 \\
\hline Control & $93 \mathrm{~b}$ & $1.55 \mathrm{~b}$ & $0.36 \mathrm{~b}$ & $0.23 \mathrm{~b}$ & $0.104 \mathrm{~b}$ & ND \\
\hline
\end{tabular}

${ }^{a}$ Dry weights of leaves, corms, and roots per plant were measured 120 days after inoculation. RMD, relative mycorrhizal dependence.

${ }^{b}$ Within each column, means followed by the same letter are not significantly different by LSD at the 5\% level. 
Table 5. Effects of arbuscubar mycorrhizal fungi on yield and quality of taro grown in the field (Experiment 2)

\begin{tabular}{lccccc}
\hline Treatment & $\begin{array}{c}\text { Yield } \\
\left(\mathrm{t} \mathrm{ha}^{-1}\right)\end{array}$ & $\begin{array}{c}\text { Water } \\
\text { content } \\
(\% \mathrm{FW})\end{array}$ & $\begin{array}{c}\text { Raw proteins } \\
\left(\mathrm{g} 100 \mathrm{~g}^{-1}\right. \\
\mathrm{FW})\end{array}$ & $\begin{array}{c}\text { Amino acids } \\
\left(\mathrm{g} 100 \mathrm{~g}^{-1}\right. \\
\mathrm{FW})\end{array}$ & $\begin{array}{c}\text { Starch } \\
\left(\mathrm{g} 100 \mathrm{~g}^{-1}\right. \\
\mathrm{FW})\end{array}$ \\
\hline $\begin{array}{l}\text { G. mosseae } \\
\text { G. versiforme }\end{array}$ & $17.6 \mathrm{a}^{a}$ & $21.2 \mathrm{a}$ & $2.34 \mathrm{a}$ & $1.78 \mathrm{a}$ & $13.2 \mathrm{a}$ \\
Control & $11.2 \mathrm{~b}$ & $\begin{array}{c}20.8 \mathrm{a} \\
17.0 \mathrm{~b}\end{array}$ & $\begin{array}{c}2.51 \mathrm{a} \\
1.96 \mathrm{~b}\end{array}$ & $1.90 \mathrm{a}$ & $13.5 \mathrm{a}$ \\
\hline
\end{tabular}

${ }^{a}$ Within each column, means followed by the same letter are not significantly different by LSD at the $5 \%$ level.

taro cultivars (Jacobs and Clarke 1993; Goenaga and Chardon 1995), further studies are needed to fully elucidate the responses of different taro cultivars to AM fungi and perhaps allow the selection of the most suitable AM fungi.

The use of micropropagated vegetable plants in horticultural production is steadily increasing (Liu and Li 2000). However, low survival rates of transplanted plants often retard their production. In the present study, the survival rate, vegetative growth, and corm development of the micropropagated taro plants, together with their economic coefficients, were significantly enhanced by AM fungal inoculation. This indicates that micropropagated taro plants have strongly mycorrhizal dependency during their growth and development.

Seedlings of vegetable crops are usually cultured on seedling beds or in containers and then transplanted into the field, which provides a convenient sowing stage of horticultural crops when inoculation with AM fungi may be performed. Arbuscular mycorrhizal fungi have also been shown to provide biological protection from certain soilborne pathogens of tomato, onion, and watermelon (Caron et al. 1986; Al-Raddad 1995; Torres-Barragan et al. 1996; Li et al. 2000, 2004) and from salinity (Copeman et al. 1996; Al-Karaki and Hammad 2001). They have been shown to influence flower biology (Liu and Li 2000; Poulton et al. 2002) and plant competition from bahiagrass (Sylvia et al. 2001) and to increase growth and yield of watermelon, capsicum, tomato, cucumber, green bean, taro, pepper, and eggplant (Al-Momany 1987; Yang et al. 1994; Li et al. 2004; Olsen et al. 1999a 1999b; Liu and Li 2001), especially under conditions of low-P availability. Even when given phosphate-containing fertilizers (Waterer and Coltman 1998; Sharma and Adholeya 2000), tomato and onion plants can still benefit from association with mycorrhizal fungi. These results also show that AM fungi continued to enhance plant growth when P fertilizer had been applied.

More field studies have been conducted on arbuscular mycorrhizas in recent years (Jakobsen 1994; Olsen et al. 1996b; Liu and Li 2001). Makus (2002) observed a tendency for tomato plants in the field inoculated with Glomus intraradices to have higher early-season yields by the second or 
third harvest, and onion bulb quality was also improved. Similar results were obtained in the present experiments: the budded taro inoculated with $G$. mosseae and $G$. versiforme and then transplanted into the field gave higher yield and quality than uninoculated controls.

Most vegetable seedlings are transplanted into the field at the five-leaf stage in China. This requires extra time and labor to manage the seedlings prior to transplanting, and the transplanted seedlings need a period of time to recover their growth. In the present experiment, the sown and inoculated paper pots were placed directly into the field, resulting in savings of labor and time and facilitating recovery of the plants. It was also found that because of restriction of root growth in the paper pots at early stages of plant growth, initial AM fungal colonization and development were presumably sufficient for the selected AM fungi to establish and compete with indigenous fungi under field conditions (Liu and Li 2001). Thus, it would be useful to investigate mycorrhizal development on seedlings in detail before and after transplanting in the field, and further studies are needed to provide standard practices for commercial production.

\section{ACKNOWLEDGMENTS}

We thank Dr. J.S. Wang for her kind gift of micropropagated taro plants, the National Natural Science Foundation of China [GZ015-11(155) and 39970498], and the Chinese Ministry of Education (Foundation for University Key Teachers) for generous financial support.

\section{REFERENCES}

Al-Karaki, G.N. and Hammad, R. (2001) Mycorrhizal influence on fruit yield and mineral content of tomato grown under salt stress. J. Plant Nutr., 24: 1311-1323.

Al-Momany, A.A.R. (1987) Effect of three vesicular arbuscular mycorrhizal isolates on growth of tomato, eggplant and pepper in a field soil. Dirasat., 14: 161-168.

Al-Raddad, A.M. (1995) Interaction of Glomus mosseae and Paecilomyces lilacinus on Meloidogyne javanica of tomato. Mycorrhiza, 5: 233-236.

Biermann, B. and Linderman, R.G. (1981) Quantifying vesicular-arbuscular mycorrhizae: A proposed method towards standardization. New Phytol., 87: 63-67.

Caron, M., Fortin, J.A., and Richard, C. (1986) Effect of Glomus intraradices on infection by Fusarium oxysporum f.sp.radicis-lycopersici in tomatoes over a 12 week period. Can. J. Botany, 64: 552-556.

Chand, H., Pearson, M.N., and Lovell, P.H. (1999) Rapid vegetative multiplication in Colocasia esculenta (L.) Schott (taro). Plant Cell Tissue Organ Cult., 55: 223-226.

Chan, L., Lu, C.T., Wei, M.L., and Lu, H.Y. (1999) Effect of planting seasons on accumulation of dry matter and nitrogen in wetland taro (Colocasia esculenta (L.) Schott)[Chinese]. Chin. J. Agric. Res., 48: 32-46.

Copeman, R.H., Martin, C.A., and Stutz, J.C. (1996) Tomato growth in response to salinity and mycorrhizal fungi from saline or nonsaline soils. Hortscience, 31: 341-344. 
FAO. (1999) FAO Production Yearbook; Rome, Italy; Vol. 53, 100.

Goenaga, R. and Chardon, U. (1995) Growth, yield and nutrient uptake of taro grown under upland conditions. J. Plant Nutr., 18: 1037-1048.

Goenaga, R., Singh, U., Beinroth, F.H., and Prasad, H. (1991) SUBSTOR-aroid: A model in the making. Agrotech Transfer, 14: 1-4.

Hatcher, L. and Stepanski, E.J. (1994) A Step-by-Step Approach to Using the SAS System for Univariate and Multivariate Statistics; SAS Institute: Cary, North Carolina.

Jacobs, B.C. and Clarke, J. (1993) Accumulation and partitioning of dry matter and nitrogen in traditional and improved cultivars of taro [Colocasia esculenta (L.) Schott] under varying nitrogen supply. Field Crops Res., 31: 317-328.

Jakobsen, I. (1994) Research approaches to study the functioning of vesicular-arbuscular mycorrhizas in the field. Plant Soil, 159: 141-147.

Kabeerathumma, S., Mohankumar, B., and Nair, P.G. (1985) Nutrient uptake by taro (Colocasia esculenta, 2. Uptake pattern of secondary and micronutrients at different stages of growth. J. Root Crops, 11: 51-56.

Kubuabola, S.L., Morrison, R.J., and Singh, U. (2000) Magnesium budget for a taro cropping system. Commun. Soil Sci. Plant Anal., 31: 2273-2282.

Li, M., Meng, X.X., Jiang, J.Q., and Liu, R.J. (2000) A preliminary study on relationship between arbuscular mycorrhizal fungi and Fusarium wilt of watermelon (in Chinese). Acta Phytopath Sinica, 30: 327-331.

Li, M., Liu, R.J., and Li, X.L. (2004) Influence of arbuscular mycorrhizal fungi on growth and Fusarium-wilt disease of water melon grown in the field (in Chinese). Acta Phytopath Sinica, 34: 456-457.

Li, Q.D., Li, Y., and Liu, J.P. (1997) Yield and nutritional value of Rosa laxa Retz pollen. Sci. Hortic. (Amst.), 71: 43-48.

Liu, R.J. (1989) Effects of vesicular-arbuscular mycorrhizas and phosphorus on water status and growth of apple. J. Plant Nutr., 12: 997-1017.

Liu, R.J. and Luo, X.S. (1994) A new method to quantify the inoculum potential of arbuscular mycorrhizal fungi. New Phytol., 128: 89-92.

Liu, R.J. and Li, X.L. (2000) Arbuscular Mycorrhiza and Application (in Chinese); Science Press: Beijing.

Liu, R.J. and Li, M. (2001) A field application test of arbuscular mycorrhizal fertilizers (in Chinese). J. Laiyang Agric College, 18: 81-84.

Makus, D.J. (2002) Mycorrhizal inoculation of tomato and onion transplants improves earliness (Abstract), XXVIth International Horticultural and Exhibition (IHC2002), Metro-Toronto Convention Centre: Toronto, Canada, 11-17.

Miyasaka, S.C. and Habte, M. (2001) Plant mechanisms and mycorrhizal symbioses to increase phosphorus uptake efficiency. Commun. Soil Sci. Plant Anal., 32: $1101-1147$.

Murashige, T. and Skoog, F. (1962) A revised medium for rapid growth and bioassays with tobacco cultures. Physiol. Plant., 15: 473-497.

Olsen, J.K., Schaefer, J.T., Edwards, D.G., Hunter, M.N., Galea, V.J., and Muller, L.M. (1999a) Effects of mycorrhizae, established from an existing intact hyphal network, on the growth response of capsicum (Capsicum annuum L.) and tomato (Lycopersicon esculentum Mill.) to five rates of applied phosphorus. Aust. J. Agric. Res., 50: 223-237.

Olsen, J.K., Schaefer, J.T., Edwards, D.G., Hunter, M.N., Galea, V.J., and Muller, L.M. (1999b) Effects of a network of mycorrhizae on capsicum (Capsicum annuum L.) grown in the field with five rates of applied phosphorus. Aust. J. Agric. Res., 50: $239-252$. 
Plenchette, C., Fortin, J.A., and Furlan, V. (1983) Growth responses of several plant species to mycorrhizae in a soil of moderate P fertility. 1. Mycorrhizal dependency under field conditions. Plant Soil, 70: 199-209.

Potty, V.P. (1978) Occurrence of vesicular-arbuscular mycorrhiza in certain tuber crops. J. Root Crops, 4: 49-50.

Poulton, J.L., Bryla, D., Koide, R.T., and Stephenson, A.G. (2002) Mycorrhizal infection and high soil phosphorus improve vegetative growth and female and male functions in tomato. New Phytol., 154: 255-264.

Sharma, M.P. and Adholeya, A. (2000) Enhanced growth and productivity following inoculation with indigenous AM fungi in four varieties of onion (Allium cepa L.) in an Alfisol. Biol. Agric. Hort., 18: 1-14.

Sylvia, D.M., Alagely, A.K., Chellemi, D.O., and Demchenko, L.W. (2001) Arbuscular mycorrhizal fungi influence tomato competition with bahiagrass. Biol. Fertil. Soils, 34: 448-452.

Torres-Barragan, A., Zavaleta-Mejia, E., Gonzalez-Chaves, C., and Ferrera-Cerrato, R. (1996) The use of arbuscular mycorrhizae to control onion white rot (Sclerotium cepivorum Berk.) under field conditions. Mycorrhiza, 6: 253-257.

Waterer, D.R. and Coltman, R.R. (1988) Phosphorus concentration and application interval influence growth and mycorrhizal infection of tomato and onion transplants. J. Am. Soci. Hortic. Sci., 113: 704-708.

Yang, X.H., Luo, X.S., and Liu, R.J. (1994) Effect of vesicular-arbuscular mycorrhiza on yield and quality of watermelon (in Chinese). Fruit Sci., 11: 117-119. 